\title{
I solation of Psychrotrophic multiple drug resistant Pseudomonas from Pasteurised milk
}

\author{
Beena A.K.*, Ranjini A.R. and Riya. T.G \\ Department of Dairy Microbiology, \\ College of Dairy Science and Technology, Mannuthy, 680651, Kerala, India. \\ * Corresponding author email : beena.ak@rediffmail.com
}

Received: 18-02-2011, Accepted: 24-03-2011, Published Online: 04-06-2011

\begin{abstract}
The present study was taken up with the objective of assessing the microbiological quality of milk processed in an organized dairy plant. The standard plate count and coliform count of all the samples tested were within the limits specified by Prevention of Food Adulteration standards. However microbiological analysis of pasteurized milk revealed a unique bacterial profile characterized by the predominance of Pseudomonas aeruginosa. Assessment of potential of the isolate to multiply at $7^{\circ} \mathrm{C}$ confirmed its psychrotrophic nature. Antibiogram of the isolate revealed that, of the seven antibiotics tested, the isolate was sensitive only to enrofloxacin. Results are suggestive of the trait of multiple drug resistance in the isolate. Such multiple drug resistant (MDR) bacteria in processed foods are potent biological hazards as there are possibilities for resistance genes to be spread to human beings via food. Isolation of such Multiple drug resistant (MDR) bacteria in pasteurised milk, an essential component of human diet is highly significant from the public health point of view. Presence of Pseudomonas species in processed products implies that post processing contamination can hinder even the quality of properly processed products. The result signifies the importance of appropriate handling practices of processed food to assure safe products at consumer level.
\end{abstract}

Keywords: psychrotroph, multiple drug resistant, Pseudomonas, pasteurized milk

\section{I ntroduction}

Psychrotrophic bacteria have been recognized as a recurring problem in refrigerated storage and distribution of perishable food products. Pseudomonas species have been implicated in the spoilage of processed milk kept under chilled condition because of their capacity to multiply under refrigerated condition with the production of thermostable proteases and lipases (Rajmohan et al, 2002). The Pseudomonas genus corresponds to a diverse and ecologically significant group of bacteria that are found in natural environments. Such a universal distribution results from the capacity of Pseudomonas species to adapt to various conditions and degrade wide range of substrates (Palleroni, 1992). Although Pseudomonas species are eliminated by pasteurization, milk is often spoiled by these Gram negative rods that gain access as post pasteurization contaminants.

There is a general consensus that the wide spread use of antimicrobial agents has imposed a strong selective pressure that has contributed multiple drug resistant (MDR) microorganisms. Foodborne bacteria including known pathogens and commensal bacteria display an extensive and diverse range of resistance to antimicrobial agents of human and veterinary importance (Alatossava and Alatossava, 2007). Any further spread of resistance among bacteria in food is likely to have an influence on public health. The European food safety authority (2008) has identified food as a source for the acquisition of Antimicrobial resistant (AMR) bacteria or bacteria borne antimicrobial resistance by humans. AMR bacteria are biological hazards associated with increased human morbidity and mortality. MDR bacteria in processed foods are potent biological hazards as there are possibilities for resistance genes to be spread to human beings via food. In the context of increasing prevalence of ABR bacteria, the antibiotic sensitivity of a psychrotrophic isolate obtained from pasteurized milk was investigated.

\section{Materials and Methods}

Representative samples of pasteurized milk were aseptically collected from Kerala Agricultural University Dairy Plant twice weekly for ten weeks spread over a period of two months. A total of twenty milk samples were analyzed for total viable cells coliforms and psychrotrophs as per the standard methods, Harrigan,W.F.(1998). 
The psychrotrophic isolates were subjected to biochemical characterization after activating the culture in nutrient broth at $37^{\circ} \mathrm{C}$ for $24 \mathrm{~h}$. Barrow and Feltham, 1993). To compare the growth kinetics of the isolate at $7^{\circ} \mathrm{C}$ and $37^{\circ} \mathrm{C}$, Calculated quantity of standardized inoculum of the isolate was added to two conical flasks with $100 \mathrm{ml}$ sterilized skim milk so as have $<10$ cells $/ \mathrm{ml}$. One flask was kept at $37^{\circ} \mathrm{C}$ and other at $7^{\circ} \mathrm{C}$. The total viable count of the samples were taken at $0,1,3,5,7$ and 9 days.

The psychrotrophic isolate was tested for their sensitivity to selected antibiotics by disc diffusion method (Bauer et al, 1966). The commercial antibiotic

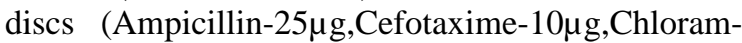
phenicol-30 $\mu \mathrm{g}$,Enrofloxacin-5 $\mu \mathrm{g}$ Gentamycin-30 $\mu \mathrm{g}$,

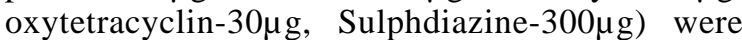
placed on Mueller Hinton Agar plates previously seeded with the standardized broth culture of the test organism. Plates were incubated at $37^{\circ} \mathrm{Cfor} 48 \mathrm{~h}$, after which zone of inhibition was measured and interpreted as per the instruction of manufacturers. Identity of the isolate was further confirmed by 16SrRNA sequencing by sending the isolate to Central Institute of Fisheries and Technology, Cochin.

\section{Results and Discussion}

According to Prevention of Food Adulteration Act (PFA, 2007) total plate count of pasteurized milk should not exceed $30,000 \mathrm{cfu} / \mathrm{ml}$. The samples analyzed in this trial showed an average Total viable count of 2.4 $\times 10^{4} \mathrm{cfu} / \mathrm{ml}$. According to PFA, coliforms which are considered as index of hygiene should be absent in $0.1 \mathrm{ml}$ of pasteurized milk. Total viable counts and coliform counts of all the samples tested in this trial were within the permitted limits. Results obtained in this trial are actually suggestive of adequate processing. However it was observed that all the standard plate count plates were characterized by the predominance of typical small circular entire smooth and shining translucent colonies. Furthermore, only this type of colony was evident in the plates used for taking psychrotrophic count. Morphological and biochemical similarity of colonies suggested that all the isolates obtained while taking psychrotrophic count exclusively belonged to the genus Pseudomonas. Identity of the isolate was confirmed as Pseudomonas aeruginosa by $16 \mathrm{SrRNA}$ sequencing. These observations are suggestive of the predominance of mesophilic psychrotrophs in the samples of processed milk.As refrigeration is an integral part of food distribution system, psychrotrophs are gaining more significance in dairy industry. Practices that are being followed in the dairy processing unit would have singled out psychrotrophs as the major category of spoilage organism (Alatossava and Alatossava, 2007).

The predominanace of Pseudomonas species in refrigerated pasteurized milk is in accordance with the findings of Ternstrom et al. (1993) .Stepaniak (1991) identified Pseudomonas species as the single most important detrimental factor determining keeping quality of pasteurised milk. Incidence of P.aeruginosa in pasteurized milk has been reported by Kumaresan and Annal Villi (2008). According to them, post processing contamination led to the predominance of heat sensitive Pseudomonas in pasteurized milk. Significant contamination by Pseudomonas can occur due to inadequately sanitized surface of milking storage and transport equipments (Mac Phee and Griffith, 2002). Anderson et al. (1990) found that P.aeruginosa could survive within exopolysaccharide masses in the interior walls of piping. Preventing the contamination of pasteurized dairy products with psychrotrophic bacteria is primarily a matter of equipment cleaning and sanitation (Beena and Prasad, 2004). Eneroth et al. (1998) reported filling step as the most critical contamination site for Gram negative rods, especially Pseudomonas. Same reasons would have contributed to the high occurrence of Pseudomonas, observed in this study. Asha (2007) also succeeded in isolating Pseudomonas aeruginosa from retail milk samples. The high spoilage potential of Pseudomonas species is not only because of its ability to multiply at refrigeration temperatures but also because of their ability to produce thermostable proteases, lipases and lecithinases (Sorhaug and Stepaniak, 1997).

The multiplication rate of the isolate at $7^{\circ} \mathrm{C}$ was comparable to that at $37^{\circ} \mathrm{C}$ The viable count after five days of inoculation was almost same in both flasks. (Fig.-1)Tolerance to a wide range of temperature is suggestive of its potential to survive in diverse range of habitats. Such organism are of greater importance in the spoilage of chilled foods. (Adam and Moss, 2000). This result is also supportive of the earlier observation of predominance of similar colonies in both TVC and psychrotrophic plates.

An isolate may be considered as multiple drug resistant if they exhibit resistance to more than two classes of antibiotic. As the isolate used in this work was found to be resistant to representatives of more than five classes of antibiotic, it may be considered as multiple drug resistant (Fig 2). The trait of multiple drug resistance for psychrotrophs have been previously reported by Alattossava and Alattossava (2007) They observed that, raw milk psychrotrophic isolates showing 


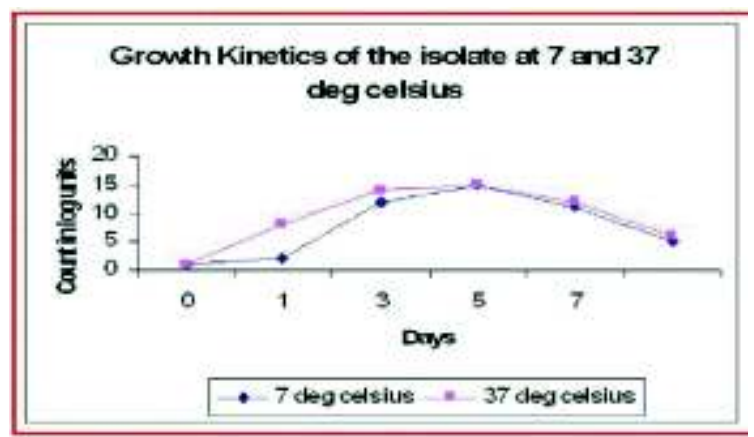

Figure-1. Growth Kinetics of the isolate at $7^{\circ} \mathrm{C}$ and $37^{\circ} \mathrm{C}$

resistance to aminoglycosides and quinolone classes were less frequent. However the psychrotrophic isolate used in this work was found to be resistant to gentamycin, an aminoglycoside antibiotic. The isolate showed sensitivity to enrofloxacin, an antibiotic belonging to quinolone group. The same authors has also reported of the possibility of accumulation of multiple antibiotic resistance traits along the cold chain of raw milk through storage and transportation. Increased frequency of multidrug resistance in Pseudomonas aeruginosa has been reported by Levy (2002) and Meyer (2005). Witte, (2000) highlighted the importance of Pseudomonads in spreading the resistance genes in rhizosphere and phytosphere. As there are reports of transfer of antibiotic resistant genes between phylogenetically distant genera, presence of MDR flora in food do pose a threat to public health.

Antimicrobial-resistant bacteria and bacteriaborne resistance genes can spread to humans via food (EFSA,2008). The potential role of food and environmental sources in the epidemiology of transferable resistance genes has gained increased attention in relation to the rapid and recent emergence of resistance to new generation antibiotics. The role of food, water and environment in the spread of apparently epidemic plasmids encoding multiple resistance is not clear but deserve immediate attention. Experimental findings are indicative of possibility of milk being a vehicle for the acquisition of AMR bacteria by humans. The increased concern for AMR bacteria in the present scenario of changing patterns in use of antimicrobial in medical and veterinary field, in food consumption and international food trade warrants in depth work in this area.

\section{Acknowledgement}

Authors acknowledge Kerala State Council for Science Technology and Environment for funding the research work. They are also thankful to Associate

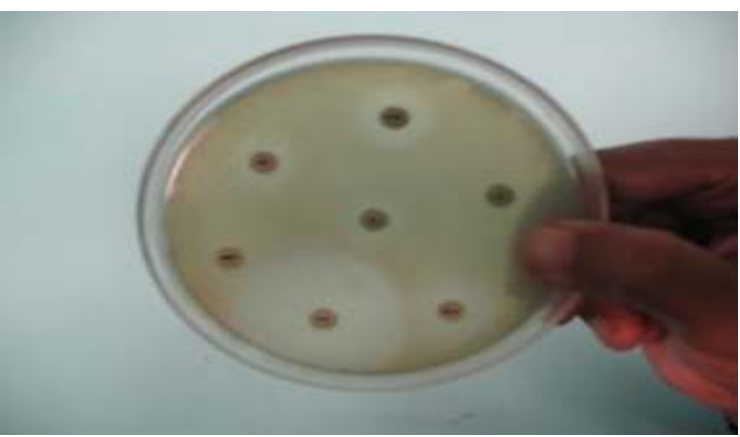

Figure-2. Antibiotic sensitivity pattern

Dean, College of Dairy Science and Technology for providing the facilities.

\section{References}

1. Adam. M.R and Moss. M.O, (2000). Food Microbiology, Panima Publishing Corporation 398p.

2. Alatossava,P.M and Alatossava,T.(2007).Antibiotic resistance of raw-milk associated psychrotrophic bacteria. Microbiol Res, 162:115-123.

3. Anderson, R.L., Holland, B.W., Carr, J.K., Bond, W.W. and Favero, M.S. (1990). Effect of disinfectants on Pseudomonads colonized on the interior surface of PVC pipes. Am. J. Publ. Hlth. 80: 17-21.

4. Asha, K. (2007). Assessment of bacterial quality and shelflife of pasteurized milk. M.V.Sc. thesis, Kerala Agricultural University, Thrissur, $174 \mathrm{p}$.

5. Barrow, C.J. and Feltham,R.K.A. (1993). Cowan and Steel's Manual for Identification of Medical Bacteria. Third edition. Cambridge University Press,London, 332p.

6. Bauer,A.W, Kirby,W.M.M., Sherris, J.C and Turk,M.(1966) Antibiotic susceptibility testing by a standardized single disk method. Am.J.Clin.Pathol. 45: 493-496.

7. Beena.,A.K and Prasad.V. (2004). Psychrotrophs-A group of organisms gaining significance in present day food-scenario. Indian Dairyman, 56, 9: 37-41.

8. Eneroth, A.A., Brendehaug, C.J. and Molin, G. (1998) Critical contamination sites in the production line of pasteurized milk. Int. Dairy J. 8: 1829-834.

9. European Food Safety Authority (2008). Scientific opinion of the panel on biological hazards antimicrobial resistance as a biological hazard. 765: $87 \mathrm{p}$.

10. Harrigan, W.F. (1998). Laboratory Methods in Food Microbiology. 3rd edition. Academic Press, California, 532p.

11. Indian Standards. (1981). Handbook of food analysis, part XI Dairy products. Bureau of Indian Standards. Manak Bhavan, 9, Bahadur Shah Zafar Marg, New Delhi, 187p.

12. Kumaresan, Gand Annalvilli, R. (2008).Incidense of Pseudomonas speies in pasteurised milk.Tamilnadu J of Vet and Animal Sci. 4:56-59.

13. Levy, S.B.(2002).Factors impacting on the problem of antibiotic resistance J.Antimicrob.Chemother.49: 25-30.

14. Mac Phee,J.D. and Griffith, M.W. (2002). Psychrotrophic bacteria: Pseudomonas spp. In Encyclopedia of Dairy Sciences, Volume 4,Academic Press,

15. Meyer,A., (2005). Prospects and challenges of developing new agents for tough Gram negatives.Curr.Opin.Pharmacol. $5: 1-5$.

16. Palleroni,N.J.(1992). Human and animal pathogenic 
pseudomonas. The Prokaryotes- A Handbook on the Biology of Bacteria. Volume. 6, Springer-verlag, New York. p.1194.

17. Rajmohan, S., Dodd, C.E.R. and Waites, W.M. (2002)

Enzymes from the isolates of P. fluorescens involved in food spoilage. J. Appl. Microbiol.93: 205-213.

18. Sorhaug, T. and Stepaniak. (1997). Psychrotrophs and their enzymes in milk and dairy products. Trends Food Sci. Technol. 8: 35-41.

19. Stepaniak. (1991). Factors affecting quality and possibilities of predicting shelf life of pasteurized and UHT heated milks.
Ital. J. Food Sci. 4:11-26.

20. Ternstrom, A., et.al. (1993). Classification of the spoilage flora of raw and pasteurized bovine milk with special reference to Pseudomonas and Bacillus. J. Appl. Bact. 75:25-34.

21. The Prevention of Food Adulteration Act, 1954 (Second Amendment) Rules, (2007). Universal Law Publishing Co. Pvt. Ltd. 350p.

22. Witte.W., (2000).Ecological impact of antibiotic use in animals on different complex microflora: environment. Int. J. Antimicrob. Agents $14: 321-325$. 